\title{
Paradigmaváltás szükségessége a sugárterápiában
}

\author{
Mayer Árpád dr. - Katona Csilla dr. - Farkas Róbert dr. - Póti Zsuzsa dr. \\ Uzsoki Utcai Kórház, Budapest
}

\begin{abstract}
A sugárterápia helye és indikációja az utóbbi évtizedben alapjaiban változott és bővült. Az új technikák és sugárbiológiai kutatások, valamint informatikai fejlesztések jelentősen javították a szolid tumorok és metasztázisok sugárkezelésében a lokális eredményességet. A komputertomográfia-alapú (egyéb metszetképalkotó vizsgálatokkal adaptált) kiegészített sugárterápiás célterület kijelölésével a tumoros és környező ép szövetek pontosabb ábrázolása vált lehetővé. Az új sugárterápiás technikák közül az intenzitás- vagy térfogatmodulált ívbesugárzással (volumetric modulated arc therapy) a célterületben a dózis optimálisan emelhető a környező ép szövetek sugárkárosodása nélkül. Ezek segítségével ugyanakkor lehetőség van új indikációkra is. Ezek között említendő az intracranialis metasztázisok mellett az extracranialis, úgynevezett oligometasztázisok közel kuratív (hosszú évekig tartó stabil állapot vagy remisszió) stereotaxiás sugárterápiája. Az oligometasztázisok között talán leglátványosabb eredményeket a máj-, tüdő- és gerincmetasztázisok egy vagy több frakcióban történő stereotaxiás sugárkezelésével lehet elérni, amelynek elengedhetetlen feltétele a kép- és esetenként a légzésvezérelt technika megléte. Orv. Hetil., 2015, 156(44), 1763-1768.
\end{abstract}

Kulcsszavak: szolid tumorok, tumoros hypoxia, sugaras károsodás, stereotaxiás sugársebészet-sugárterápia, oligometasztázisok, hagyományostól eltérő frakcionálás

\section{The need for a paradigm shift in radiotherapy}

The status and indications of radiotherapy have significantly changed in the past decade because novel techniques, radiobiological research and major advances in informatics have made better local control possible. Using supplemented marking of the target volume with computer tomography based other image-making methods adapted made it possible to define the tumor and intact surrounding tissues more precisely. With novel radiotherapy techniques the dosage of the homogenity and the covering in the target volume can be raised optimally, especially with intensity modulated arc radiotherapy (volumetric modulated arc therapy) without causing radiation injury or damage to intact surrounding tissues. Furthermore, with novel techniques and target volume marking, new indications have appeared in clinical practice and besides sterotactic radiotherapy for intracranial metastases, the extracranial so-called oligometastic conditions can be maintained close to a curative state (or in remission) for many years. Among these, perhaps the most striking is the stereotactic radiotherapy treatment of liver, lung and spinal cord metastases in one or more fractions, for which the indispensable condition is the image or respiratory guided technique.

Keywords: solid tumors, tumor hypoxia, radiation injuri, stereotactic radiosurgery or radiotherapy, oligometastasis, alterated fractionation

Mayer, Á., Katona, Cs., Farkas, R., Póti, Zs. [The need for a paradigm shift in radiotherapy]. Orv. Hetil., 2015, $156(44), 1763-1768$.

(Beérkezett: 2015. augusztus 19.; elfogadva: 2015. szeptember 17.)

\section{Rövidítések}

$\mathrm{BED}=$ biológiailag azonos (ekvivalens) dózis; IMRT = intenzitásmodulált sugárterápia; NSCL = nem kissejtes tüdőrák; RapidArc therapy = VMAT-tal azonos, másik gyártó terméke;
SBRT $=($ stereotactic body radiotherapy $)$ stereotaxiás test-sugárterápia; TCP $=$ (tumor control probability) daganatmentesség valószínúsége; VMAT = térfogathoz igazított (modulált) ívsugár-terápia 
A röntgensugár 1895-ös (C. V. Röntgen) és a radioaktivitás 1896-os (H. Bequerel) felfedezését követően rövid időn belül, már 1903-ban szövettanilag igazolt bőrtumorok sikeres besugárzása történt, illetve Ra226 tűkkel mélyebben fekvő malignus daganatok kezelése vált lehetővé, amelyekről közlemények is rendelkezésünkre állnak [1].

A sugárterápiát kezdetben eseti megfigyelések alapján, individuálisan megállapított dózisokkal végezték, miután a sugárbiológiai és sugárfizikai alapok, valamint a klinikai tapasztalatok akkor még hiányoztak. Ezt a korszakot nevezhetjük empirikus (tapasztalati/megfigyeléses) sugárterápiának egészen az 1960-as évek közepéig. Ezt követte az úgynevezett racionális sugárterápia, köszönhetően a technikai, számítástechnikai fejlesztéseknek, a klinikai tapasztalatoknak és a sugárbiológiai kutatásoknak (például hatást/mellékhatást elsődlegesen és másodlagosan befolyásoló tényezők, lokális oxigenizáció hatása a terápiás válaszra stb.).

Ugyanakkor mindezek még nem jelenthettek tudatos paradigma- (szemlélet-) váltást, hiszen a sugárterápiát gyakran csak tüneti/palliatív kezelésre használták, vagyis annak tényleges hatását és lehetőségeit még nem mérték fel. További fordulópontot az 1990-es évek elején elterjedt CT-alapú 3D-ben (dimenzió) megjelenített sugárterápiás célterület kijelölése jelentett, ahogy ezt Purdy és munkatársainak 1992-ben írt közleményéből megtudhatjuk [2]. A tumoros célterület közel 90-95\%-os lefedettségű vagy konformitású, homogén besugárzása vált lehetővé a környező ép szövetek védelme mellett, mindenekelőtt lineáris gyorsítókkal. A sugárterápia ezáltal egyre inkább integrálódott a malignus daganatok kuratív ellátásának más formáihoz, elsősorban a sebészethez. Körvonalazódnak azok az indikációk, ahol a sugárterápia a sebészi/nem sebészi módszerekkel (kemoterápia/hőterápia) kombinálva az eredményeket látványosan javítja. A kombinált módszerek között természetesen voltak úgynevezett „high tec” kategóriába sorolhatók is, az érdekesség kedvéért említendő a Nag és mtsai által kidolgozott radioimmunoguided-intraoperatív radioterápia -, amely mind a mai napig nem tartozik a klinikai rutinhoz [3], ugyanakkor az onkológia multidiszciplináris fontosságára utal (izotópdiagnosztika, sebészet és sugárterápia).

Tehát látható, a sugárterápiás gyakorlatban egyre tudatosabbá válik a szemléletváltás. Az új daganatsebészi módszerekkel, új daganatellenes gyógyszerekkel és célzott kezelésekkel elért eredmények „eufóriája” közepette e klinikumok képviselői hajlamosak megfeledkezni (vagy nem ismerik) a sugárterápia „újkori” fejlesztéseiről és eredményeiről.

A metasztázisok korábban palliatív (tüneti) szándékú sugárkezelését egyre inkább a közel kuratív szándékú sugárterápia váltja fel, de hasonlóan javultak az eredmények a perifériás nem kissejtes tüdődaganatokban is inoperabilitás (belgyógyászati okok miatt) esetén [4].
A tudatos szemlélet/paradigma váltáshoz elengedhetetlenül szükséges az új generációs lineáris gyorsító és besugárzás tervezés/ellenőrzés, valamint dozimetria megléte és a sugárbiológia alaposabb ismerete.

Belka és mtsai, valamint Coleman és mtsai 2002-ben, illetve 2003-ban összefoglaló tanulmányukban az ionizáló sugárzás hatásmechanizmusát részletesen leírják, ez alapján érthető, hogy a lokális eredményesség mellett bizony korai/késői szöveti károsodások is előfordulhatnak $[5,6]$. Ezek között említendő a szöveti fibrosis, teleangiectasia, szöveti nekrózis, amelyek szervi (hólyag, bél, szájnyálkahártya, gerinc, tüdő stb.) károsodásokhoz vezetnek. Különböző súlyosságú/fokozatú sugárkárosodások értékelésére nemzetközi ajánlás áll rendelkezésünkre [7].

A korszerú képi diagnosztikával (PET/CT, MR stb.) és klinikai leírással ennek mértékét úgynevezett skálarendszeren lehet rögzíteni. Saját beteganyagunkban az emlődaganatok MDR (medium dose rate - közepes dózisteljesítményü) interstitialis (szövetközi) brachytherapiáját követő késői sugárkárosodását ultrahanggal, MRrel és SPECT/PET/CT-vel is vizsgáltuk Póti és munkatársainak módszerével [8]. Hasonló feldolgozást készítettünk az előrehaladott méhnyakrákok egyedüli sugárterápiáját követő korai/késői sugárkárosodásokról is [9].

\section{Sugárterápiás célterület adekvát kijelölése}

A lineáris gyorsítóval történő perkután sugárterápiában a biológiai képalkotás és a biológiai konformalitás fogalmára Ling és mtsai már a 2000-ben írt közleményükben utalnak [4]. Ehhez tartozik a PET/CT, amely a CT-alapú besugárzástervezés egyik úgynevezett adaptív módszere az MR és MR-spektrometria mellett. Ezek segítségével a tumor morfológiai kiterjedésén túl, a tumorinvázió mélységét is ábrázolni lehet. A besugárzástervezésben a CT-alapú, adaptív PET/CT-vel és/vagy MR-rel kiegészített módszert biológiailag optimalizált célterület-kijelölésnek hívjuk [10]. Több daganatlokalizációban a PET/CT alapú besugárzástervezést elengedhetetlen feltételnek tartjuk, többek között nyelőcsődaganatokban, fej-nyaki daganatokban, amelyekben saját tapasztalatokkal is rendelkezünk [11]. Ugyanakkor a brachytherapiában mindenekelőtt a nőgyógyászati tumorok kezelésében az MR-adaptált CT-alapú tervezéssel a tumoros célterület, védendő szervek (mindenekelőtt a hólyag és végbél) kijelölése tűnik pontosabbnak. A munka időigényessége miatt nem sok intézetben tartozik a napi rutinmódszerek közé [4, 12].

\section{Tumoros oxigenizáció}

A sugárterápia lokális hatásának egyik legfontosabb feltétele a tumoron belüli és közvetlen környezetében az oxigenizáció foka. Régen ismert tény, hogy a humán tumorok 60\%-ában hypoxiás viszonyok vannak, ennek be- 
folyásolhatóságáról Overgaard 2007-ben összefoglaló közleményt írt [13].

Speciális tracerrel (jelöléssel) PET/CT vizsgálattal a tumor lokális oxigenizációjának mértékére is választ kapunk, amely meghatározza a prognózist és a dózisemelés szükségességét is bizonyos „célterületen belüli szubvolumenben" $[13,14]$.

A hypoxiás/anoxiás környezetben közismert az alacsonyabb fokú sugárérzékenység, rezisztencia, illetve a nekrózis veszélye [15]. Zips és mtsai állatkísérletes tanulmányukban igazolták, hogy 0,5 Hgmm alatti lokális oxigénnyomás esetén a hypoxiás sejtek 2,5-3-szor rezisztensebbek ugyanazon dózisra, mint a normális oxigenizációjú sejtek [14].

\section{Stereotaxiás testradioterápia (stereotactic body radiotherapy - SBRT) sugárbiológiai alapjai, hagyományostól eltérő frakcionálás}

A korszerü, képvezérelt sugárterápiás (a besugárzás pontosságának ellenőrzése/növelése a besugárzókészülékekbe integrált, többféle képalkotó eljárás segítségével) és betegrögzítési technikák fejlődésével minimalizálható a céltérfogat körüli biztonsági margók bizonytalansága, csökkenthető lett a védendő szervek dózisterhelése, azaz a céltérfogat lényegesen pontosabb besugárzását tette lehetővé. A hagyományos módszerek esetén a céltérfogat beállítása általában a csontos struktúrák figyelembevételével történt, a modern besugárzókészülékekbe épített cone-beam CT- vagy légzésvezérlés ma már lehetővé teszi az egyes szervek kezelések közötti vagy akár kezelés alatti elmozdulásának figyelembevételét. A modern sugárterápiás eljárásokkal, mint az IMRT (intenzitásmodulált sugárkezelés) vagy a VMAT (dinamikus, térfogathoz adaptált ívradioterápia intenzitásmodulációval) a kezelések eredményessége javítható, a nem kívánt mellékhatások kialakulásának valószínűsége pedig csökkenthető (1. ábra).
Korábbi közleményünkben a technikai feltételekről, primer tumorok, metasztázisok kezelésében elért eredményekről részletesen is beszámoltunk.

A sugárkezelések kezdetekor a múlt század elején számos megfigyelés igazolta, hogy az egy frakcióban leadott besugárzást a dózis függvényében jelentős normál szöveti toxicitás kíséri. A frakciódózis csökkentésével, az összkezelési időt növelve, javuló terápiás eredmények mellett az egészséges szövetek védelme is megvalósítható. A sugárbiológia törvényszerűségeit felismerve a frakcionált sugárterápia (50-70 Gy/1,6-2,0 Gy) rövid időn belül a mindennapi gyakorlat részévé vált, $s$ jelenti ma is a sugárkezelések alapját a legtöbb daganatlokalizációban. Az irradiáció teljes időtartama a fenti paraméterek mellett - a szükséges összdózis nagyságától függően - általában 5-8 hét. A hagyományosnál kisebb egyszeri dózisok alkalmazása esetén hiperfrakcionálásról, nagyobb napi frakciók esetén hipofrakcionálásról beszélünk.

A robbanásszerú technikai fejlödésnek köszönhetően az elmúlt 10-15 évben a hipofrakcionált sugárkezelések (SBRT) térhódítása észlelhető világszerte. Az SBRT során 1-5 frakcióban 8-30 Gy adható le a besugarazni kívánt céltérfogatra a dóziseloszlások legmagasabb konformalitása mellett. Az összkezelési idő lényegesen csökkenthető: a hagyományos 6 hét-két hónap helyett döntően egy hét alatt komplettálódik a besugárzás.

A hipofrakcionált sugárkezelés az eddigi - elsősorban az alacsonyobb frakciódózisokra (2,5-4 Gy/frakció) érvényes - sugárbiológiai ismereteink szerint, terápiás előnyt a lassan proliferáló, nagy repairkapacitással rendelkező daganatok (prosztata-, emlődaganat) esetén jelenthet $[16,17]$, a hasonlóan lassú proliferációs képességgel rendelkező normál szövetek károsodásának az esélyét viszont növeli. Hipofrakcionálás esetén így nagyobb arányban várhatók a kezelések után hónapokkal, akár évekkel megjelenő késői szövődmények, amelyek általában irreverzibilisek, progresszív károsodások és döntően tartós életminőség-romláshoz vezetnek.

A késői sugárkárosodások elkerülése érdekében az első óvatos SBRT-kezelések elsősorban palliatív indikációban

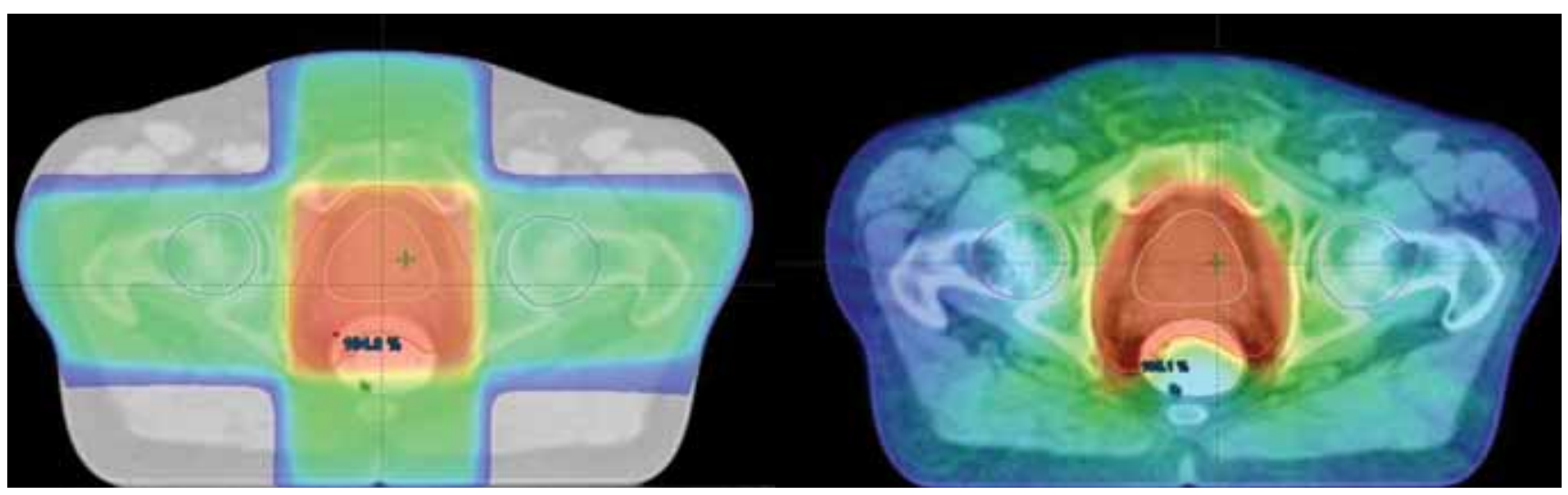

1. ábra

3D CRT- és VMAT-kezelés dóziseloszlása prosztatát és vesicula seminalisokat magában foglaló céltérfogat esetén. VMAT-technikával konformálisabb besugárzás érhető el és a végbél jobban védhető 
folytak, olyan esetekben, ahol a betegek kis eséllyel élték meg a szövődmények kialakulását.

A preklinikai/állatkísérletes modellek után a humán klinikai fázis I/II vizsgálatokat azonban meglepő módon várakozáson felüli sikeresség kísérte szinte minden indikációs körben, amelynek következtében újabb és újabb vizsgálatok indultak a dozírozási sémák/dóziskorlátok pontosítására. Az indikációs kör egyre bővül, ma már az SBRT-kezelések kuratív intencióval is folynak, kiváló eredményességgel és a 3-5 éves követési adatok alapján biztonságosan. Míg azonban a kivitelezéséhez szükséges technikai fejlődés (IMRT, ívbesugárzás, képés légzésvezérlés) és az ezzel járó előnyök (konformalitás növelése, sugárkárosodások csökkentése, kapacitásbővülés, betegkényelmi szempontok) vitathatatlanok, az SBRT sugárbiológiai jellemzői nem tisztázottak minden részletükben.

$\mathrm{Az}$ eddigi terápiás eredmények értékelésére gyakran ellentmondó magyarázatok születnek. Több adat mutat abba az irányba, hogy a hagyományos frakcionált sugárterápia ( 1,6-2,2 Gy/frakció) sugárbiológiai törvényszerúségeivel nem lehet magyarázni az SBRT-kezelések meglepően jó klinikai eredményességét. Ismert, hogy nem túl magas (<60 Gy) összdózisú SBRT-kezelésekkel kiváló lokális kontroll érhető el, akár nagyobb daganatos laesiók esetén is. Sanuki és mtsai $\geq 5 \mathrm{~cm}$ nagyságú májdaganatok 54 Gy $(3 \times 18$ Gy) összgócdózisú SBRT-kezelését követően $90 \%$ feletti lokális daganatkontrollról számoltak be.

Az SBRT-kezelések nagyfokú effektivitását több tényező összeadott hatása magyarázhatja. Magas frakciódózisoknál (>8-10 Gy) a DNS kettős lánctörésében megnyilvánuló direkt sejtpusztulás mellett további mechanizmusok is részt kell, hogy vegyenek a terápiás válasz kialakításában. Fuks és Kolesnick arról számoltak be, hogy nagy sugárdózisoknál egy gyors, úgynevezett sphingomyelinase-dependens vascularis kollapszus alakul ki, amely megnöveli az irradiáció daganatellenes hatását $[18,19]$. Az SBRT ablatív természetéból fakadóan a daganat érrendszerének tartós (esetenként irreverzibilis) sérülésén keresztül jelentős másodlagos sejtpusztulás jön létre, ami tovább fokozza a hatékonyságot [20].

Harmadrészt az SBRT során a daganatsejtek antigenitásának növekedése, a daganatellenes immunválasz növekedése is jelentős [21], bár az egyelőre nem tisztázott, hogy ez a hatás a magasabb frakciódózisok esetén menynyivel nagyobb a hagyományos frakcionálású besugárzásokéhoz képest [22]. Valószínúleg mindhárom tényező együttes hatására van szükség.

A sugárkezelések hatására kialakuló hatás/mellékhatás numerikus jellemzésére használt, legáltalánosabban elterjedt és a konvencionálisan frakcionált sugárterápia jelenségeit legjobban leíró matematikai modell az LQ (lineáris-quadratikus) modell. Segítségével a különböző kezelések összehasonlíthatóvá, az eltérő frakciódózisú/ összdózisú sémák biológiai hatásai adott határokon belül jól becsülhetővé váltak.
Az LQ-modell és módosításai alapján számított BED (biológiai effektív dózis) -értékek SBRT során extrém magasak. A kérdés az, hogy a hipofrakcionált (SBRT) kezelések sikere a fenti tényezők szummációjából adódik (amit sokan „új sugárbiológia”-ként is neveznek) vagy a nagyon magas BED-értékekből automatikusan következtethető.

Élénk tudományos vita folyik a kérdésről. Mehta és mtsai korai (I. stádiumú) NSCLC-daganatok SBRT-kezelését követően a klinikai adatok alapján lineáris összefüggést találtak a BED és a TCP (tumor control probability) között: minél magasabbak a BED-értékek, annál nagyobb lesz a TCP a hipofrakcionált besugárzások során. A kezelések eredményességét a dóziseszkaláció és nem egy „új biológia” magyarázza [23].

Mások szerint ugyanakkor magas ( $\geq 6 \mathrm{~Gy}$ ) frakciódózisú irradiáció esetén az LQ-modell és a BED-értékek nem használhatók a hatás/mellékhatás megbecsülésére.

Ismert, hogy hagyományosan frakcionált sugárkezelések során az irradiáció daganatra kifejtett hatását 5 tényezővel lehet jellemezni (5R):

1. szubletális károsodások javítása (repair),

2. a sugárkezelést követóen a daganatsejtek repopulációja,

3. a daganatsejtek redisztribúciója a sejtciklusban,

4. a túlélő sejtek reoxigenizációja,

5. intrinszik radioszenzitivitás.

Az SBRT-kezelések látszólag több évtizedes sugárbiológiai dogmákkal szakítanak, mert az alacsony frakciódózisú sugárterápiát jellemző $5 \mathrm{R}$-rel a hipofrakcionált besugárzások nem írhatók le [24]. Nagy frakciódózisú irradiáció során jelentôs vascularis károsodás következik be, emiatt az intratumorális mikrokörnyezet hypoxiás / savas lesz, ami a hypoxiás sejteket nemcsak megvédi a reoxigenizációtól, hanem egyben indirekt sejthalálhoz is vezet. Az SBRT-kezelések mindemellett alkalmanként hosszú ideig tartanak, ami lehetővé teszi az irradiáció időtartama alatt a szubletális károsodások kijavítását. A redisztribúció sem jellemző, mert a nagy dózisok meggátolják a sejtciklus progresszióját, a daganatsejt az interfázis azon szakaszában, ahol a besugárzás érte, el fog pusztulni. A daganatsejtek repopulációja elhanyagolható, tekintettel arra, hogy a kezelések 1-2 héten belül komplettálódnak.

\section{Megbeszélés}

A bevezetésben már említett paradigmaváltás törvényszerűsége és szükségessége elsősorban a technikai feltételektől és sugárbiológiai ismeretektől függ.

Az újkori, mindenekelőtt a 2010-es évek utáni szemléletváltásban elsődleges a klinikus igénye, olyan technikák alkalmazása, amelyekben a betegkényelem is szerepet játszik - rövidebb összkezelési időben ugyanolyan onkológiai eredményesség és mellékhatás mellett történjen a szolid tumorok kezelése. Ezen állítás alátámasztására a prosztata- és emlőrák sugárkezelése szolgál példát - 
két gyakori indikáció körben az elmúlt 10 évben miként változott mindenekelőtt a sugárkezelés frakcionálása

Számos randomizált vizsgálat bizonyította, hogy alacsony és közepes rizikójú, szervre lokalizált prosztatadaganatos beteg mérsékelt hipofrakcionált sugárkezelése hatékony és biztonságos eljárás, szemben a hagyományos frakcionálással, ahol az összdózis 74-78 Gy [25, 26].

A vizsgálatok alapján 4-8 éves követés után az 5 éves biokémiai relapsusmentességben (77-96\%) nincs szignifikáns különbség a hagyományos frakcionálással leadott 70 Gy feletti dózisokhoz képest. Sőt kevésbé differenciált daganatok ( $\geq$ Gleason-score $4+3$ ) esetén jobb biokémiai kontrollt eredményezett a hipofrakcionálás.

Igaz, alacsony relapsuskockázatú betegnél hosszabb követés kell a hatékonyság pontos megítéléséhez. A kezelés biztonságosságát ugyanakkor igazolja, hogy $\geq$ Grade 2 gastrointestinalis és genitourinalis mellékhatások aránya (2-20\%) nem nőtt szignifikánsan a hagyományos frakcionáláshoz képest [26]. Ebben a lokalizációban is az extrém hipofrakcionálás indokolt lehet, 5 Gy-t meghaladó frakciók leadásával, természetesen SBRT formájában.

Emlőmegtartó mütétet követően szinte mindig indokolt a maradék emlőállomány besugárzása, amely történhet hipofrakcionált formában is. A konvencionális frakcionálással összehasonlítva ennek két oka van: egyfelől a frakciódózis-emelés (hipofrakcionálás) miatt nő a tumorkontroll (lokális eredményesség), ugyanakkor a megtartott egészséges szövetek károsodása nem emelkedik. Sok klinikai vizsgálat indult, amelyek egy része a terápiás index javulását, más része pedig a megnövelt frakciódózis ellenére a nem rosszabb normális szöveti toxicitását (mellékhatások nem növekednek) szeretné bizonyítani.

Az Egyesült Királyságban 1986 óta folynak a hipofrakcionált emlőbesugárzással kapcsolatos vizsgálatok. A START-vizsgálatok megállapították, hogy a 3 hét alatt leadott 40 Gy 15 frakcióban nem eredményez rosszabb lokoregionális kontrollt a standard $25 \times 2$ Gy besugárzással összehasonlítva, viszont a teleangiectasia, ödéma, emlődeformitás előfordulása szignifikánsan kevesebb volt [26]. Ezen vizsgálatok alapján az Egyesült Királyságban a 15 frakcióban leadott 40 Gy a standard kezelés.

A FAST vizsgálat ennél is tovább ment, azt vizsgálta, meddig lehet emelni a frakciódózist az akut toxicitás elfogadhatatlan mértékű emelkedése nélkül. 28,5, illetve 30 Gy összdózist adtak le 5 frakcióban 5 hét alatt, az akut mellékhatások előfordulása összehasonlítható mértékű volt [27]. Feltételezhetően a FAST Forward fázis III vizsgálattal - amelyben a 15 frakcióban leadott 40 Gy-t hasonlítják össze az akcelerált hipofrakcionált besugárzással, így a betegek 5 nap alatt 5 frakcióban összesen 26-27 Gy-t kapnak - az eredmények tovább javulnak. Az összkezelési idő rövidülése által a repopuláció csökkenhet, a korán reagáló normál szöveti károsodás azonban növekedhet, habár ezt a korai klinikai vizsgálatok még nem igazolták. A hipofrakcionált emlőbesugárzás egy lehetséges opció jó prognózisú, idős emlőtumoros betegek számára, akik egy hosszabb kezelést nem tolerálnának.

Anyagi támogatás: A közlemény megírása anyagi támogatásban nem részesült.

Szerzôi munkamegosztás: A kézirat megírásában minden szerző részt vett. A cikk végleges változatát valamennyi szerző elolvasta és jóváhagyta.

Érdekeltségek: A szerzőknek nincsenek érdekeltségeik.

\section{Irodalom}

[1] Kisfaludy, P.: The treatment of malignant tumours with radium point of view by chirurgeon. [A rosszindulatú daganatok rádiummal való gyógyítása sebészeti vonatkozásban.] Magyar Orvosi Könyvkiadó Társulat, Budapest, 1934. [Hungarian]

[2] Purdy, J. A.: Photon dose calculations for three-dimensional radiation treatment planning. Semin. Radiat. Oncol., 1992, 2(4), 235-245.

[3] Nag, S., Martinez-Monge, R., Nieroda, C., et al.: Radioimmunoguided-intraoperative radiation therapy in colorectal carcinoma: a new technique to precisely define the clinical target volume. Int. J. Radiat. Oncol. Biol. Phys., 1999, 44(1), 133-137.

[4] Ling, C. C., Humm, J., Larson, S., et al.: Towards multidimensional radiotherapy (MD-CRT): biological imaging and biological conformality. Int. J. Radiat. Oncol. Biol. Phys., 2000, 47(3), $551-560$.

[5] Belka, C., Betsch, A., Marini, P., et al.: Zelltodliganden in Kombination mit ionisierender Strahlung: Rationale und Kenntnisstand. Strahlenther. Oncol., 2003, 179(3), 141-151.

[6] Coleman, C. N.: Radiation oncology - linking technology and biology in the treatment of cancer. Acta Oncol., 2002, 4l(1), 6-13.

[7] Dolezel, M., Odrazka, K., Vanasek, J., et al.: MRI-based pre-planning in patients with cervical cancer treated with three-dimensional brachytherapy. Br. J. Radiol., 2011, 84(1005), 850-856.

[8] Póti, Zs., Nemeskéri, Cs., Fekésházy, A., et al.: Partial breast irradiation with interstitial ${ }^{60} \mathrm{CO}$ brachytherapy results in frequent grade 3 or 4 toxicity. Evidence based on a 12-year follow-up of 70 patients. Int. J. Radiat. Oncol. Biol. Phys., 2004, 58(4), 1022-1033.

[9] Mayer, A., Nemeskéri, Cs., Petneházi, Cs., et al.: Primary radiotherapy of stage IIA/B-IIIB cervical carcinoma. A comparison of continuous versus sequential regimens. Strahlenther. Onkol., 2004, 180(4), 209-215.

[10] Paulino, A. C., Teh, B. S.: PET-CT in radiotherapy treatment planning. Saunders, Elsevier, Philadelphia, 2008.

[11] Sinkó, D., Klinkó, T., Weisz, Cs., et al.: A PET/CT based radiotherapy treatment planning in head and neck cancers. [PET/CT alapú besugárzástervezéssel szerzett tapasztalatok fej-nyaki tumorokban.] Orv. Hetil., 2009, 150(30), 1403-1406. [Hungarian]

[12] Bollineni, V. R., Koole, M. J., Pruim, J., et al.: Dynamics of tumor hypoxia assessed by ${ }^{18} \mathrm{~F}$-FAZA PET/CT in head and neck and lung cancer patients during chemoradiation: Possible implications for radiotherapy treatment planning strategies. Radiother. Oncol., 2014, 113(2), 198-203.

[13] Overgaard, J.: Hypoxic radiosensitisation: adored and ignored. J. Clin. Oncol., 2007, 25(26), 4066-4074. 
[14] Zips, D., Böke, S., Kroeber, T., et al.: Prognostic value of radiobiological hypoxia during fractionated irradiation for local tumor control. Strahlenther. Onkol., 2011, 187(5), 306-310.

[15] Lubgan, D., Ziegaus, A., Semrau, S., et al.: Effective local control of vertebral metastases by simultaneous integrated boost radiotherapy: preliminary results. Strahlenther. Onkol., 2015, 191(3), 264-271.

[16] Perez, C. A., Brady, L. W.: Late radiation morbidity scorin criteria (RTOG/EORTC). In: Perez, C. A., Brady, L. W. (eds.): Principles and Practice of Radiation Oncology. Lippincott, Philadelphia, 2007.

[17] Ray, K. J., Sibson, N. R., Kiltie, A. E.: Treatment of breast and prostate cancer by hypofractionated radiotherapy: potential risks and benefits. Clin. Oncol., 2015, 27(7), 420-426.

[18] Garcia-Barros, M., Paris, F., Cordon-Cardo, C., et al.: Tumor response to radiotherapy regulated by endothelial cell apoptosis. Science, 2003, 300(5622), 1155-1159.

[19] Fuks, Z., Kolesnick, R.: Engaging the vascular component of the tumor response. Cancer Cell, 2005, 8(2), 89-91.

[20] Park, H. J., Griffin, R. J., Hui, S., et al.: Radiation-induced vascular damage in tumors: Implications of vascular damage in ablative hypofractionated radiotherapy (SBRT and SRS). Radiat. Res., 2012, 177(3), 311-327.

[21] Lugade, A. A., Moran, J. P., Gerber, S. A., et al.: Local radiation therapy of B 16 melanoma tumors increases the generation of tumor antigen-specific effector cells that traffic to the tumor. J. Immunol., 2005, 174(12), 7516-7523.
[22] Dewan, M. Z., Galloway, A. E., Kawashima, N., et al.: Fractionated but not single-dose radiotherapy induces an immune-mediated abscopal effect when combined with anti-CTLA-4 antibody. Clin. Cancer Res., 2009, 15(17), 5379-5388.

[23] Mehta, N., King, C. R., Agazaryan, N., et al.: Stereotactic body radiation therapy and 3-dimensional conformal radiotherapy for stage I non-small cell lung cancer: A pooled analysis of biological equivalent dose and local control. Pract. Radiat. Oncol., 2012, 2(4), 288-295.

[24] Brown, J. M., Carlson, D. J., Brenner, D. J.: The tumor radiobiology of SRS and SBRT: are more than the 5 Rs involved? Int. J. Radiat. Oncol. Biol. Phys., 2014, 88(2), 254-262.

[25] Koontz, B. F., Bossi, A., Cozzarini, C., et al.: A systematic review of hypofractionation for primary management of prostate cancer. Eur. Urol., 2015, 68(4), 683-691.

[26] Haviland, J. S., Owen, J. R., Dewar, J. A., et al.: The UK standardisation of breast radiotherapy (START) trials of radiotherapy hypofractionation for treatment of early breast cancer: 10-year follow-up results of two randomised controlled trials. Lancet Oncol., 2013, 14(11), 1086-1094.

[27] Agrawal, R. K., Alhasso, A., Barrett-Lee, P. J., et al.: First results of the randomised UK FAST Trial of radiotherapy hypofractionation for treatment of early breast cancer (CRUKE/04/015). Radiother. Oncol., 2011, 100(1), 93-100.

(Mayer Árpád dr., Budapest, Uzsoki u. 29-41., 1145 e-mail: mayera@hu.inter.net)

\section{A rendezvények és kongresszusok híranyagának leadása}

a lap megjelenése előtt legalább 40 nappal lehetséges, a 6 hetes nyomdai átfutás miatt. Kérjük megrendelőink szíves megértését.

A híranyagokat a következő címre kérjük:

Orvosi Hetilap titkársága: Budai.Edit@akkrt.hu

Akadémiai Kiadó Zrt. 